KAMILA ZIÓtKOWSKA-WEISS

Uniwersytet Pedagogiczny w Krakowie, Polska - Pedagogical University of Cracow

\title{
Ocena nauczania podstaw przedsiębiorczości przez uczniów liceum ogólnokształcącego
}

\author{
Assessment of Basics of Entrepreneurship by Students of the General Education \\ Secondary School
}

Streszczenie: Przedmiot podstawy przedsiębiorczości pomaga zrozumieć młodemu człowiekowi mechanizmy funkcjonowania gospodarki rynkowej, przygotowuje do planowania przyszłej kariery zawodowej, kształtuje kompetencje sprawnego komunikowania się, a także przygotowuje do planowania i realizacji przedsięwzięć w otaczającym go środowisku. Niniejszy artykuł ma na celu ukazanie poglądów młodzieży dotyczących spraw związanych z realizacją przedmiotu podstawy przedsiębiorczości w szkołach ponadgimnazjalnych. W pracy zostaną przedstawione wyniki badań, które zostały przeprowadzone w maju 2015 r. wśród uczniów andrychowskiego Liceum Ogólnokształcącego im. Marii Skłodowskiej-Curie. Badania podjęto, aby dokonać analizy realizacji celów, zadań oraz treści kształcenia przedmiotu podstawy przedsiębiorczości. Celem badań było zapoznanie się z opinią uczniów na temat tego, które zagadnienia według nich są najbardziej przydatne w życiu dorosłym oraz które zagadnienia i treści najbardziej ich interesują. Badania te stanowią kontynuację badań przeprowadzonych przez autorkę w 2013 r. wśród uczniów klas trzecich oraz pierwszych andrychowskiego liceum. Celem artykułu jest ukazanie opinii tych samych uczniów po upływie dwóch lat od pierwszego badania oraz próba odpowiedzi na pytanie - co zmieniło się w ich opinii i jak zapatrują się oni na kwestie związane $\mathrm{z}$ realizacją przedmiotu podstawy przedsiębiorczości.

\begin{abstract}
The subject 'Basics of Entrepreneurship' allows a young person to understand the mechanisms of functioning of the market economy, prepares to plan the future professional career, shapes the competences of fluent communication as well as prepares to plan and accomplish the enterprises in the surrounding environment. This paper aims at presenting the viewpoints of young people concerning the issues related to completion of the subject 'Basics of Entrepreneurship' at secondary schools. The results of the research that was conducted in May 2015 among the students of the Maria Skłodowska-Curie General Education Secondary School in Andrychów will be presented in the paper. The research was carried out to analyze the accomplishment of objectives, tasks and educational content of the subject of 'Basics of Entrepreneurship'. The purpose of the research was to familiarize with the students' opinion as well as to get to know which aspects and content are the most useful in the adult life in their opinion and which of them interest them most. This research constitutes the continuation of the one conducted by the author in the year 2013 among the third and first class students of the Andrychów General Education Secondary School. The objective of the paper is to present the opinions of the same students after the period of two years following the first research as well as an attempt to answer the question what has
\end{abstract}


changed in their opinion and how they perceive the issues related to completion of the subject 'Basics of Entrepreneurship'.

Słowa kluczowe: edukacja; gospodarka rynkowa; nauka; przedsiębiorczość; szkoła

Key words: education; entrepreneurship; learning; market economy; school

Otrzymano: 11 listopada 2015

Received: 11 November 2015

Zaakceptowano: 7 marca 2016

Accepted: 7 March 2016

\section{Sugerowana cytacja/Suggested citation:}

Ziółkowska-Weiss, K. (2016). Ocena nauczania podstaw przedsiębiorczości przez uczniów liceum ogólnokształcącego. Przedsiębiorczość - Edukacja, 12, 457-470.

\section{Wstęp}

Przyjęte po 1989 r. rozwiązania w systemie oświaty w Polsce w sposób istotny zmieniły nie tylko system szkolnictwa, lecz także kanon wykształcenia ogólnego. Wyraźnie zostały zaakcentowane m.in.: przygotowanie obywateli do życia w demokracji, gospodarka oparta na zasadach liberalizmu i prawa rynku, pluralizm polityczny i kulturowy, członkostwo w Unii Europejskiej, globalny i lokalny kontekst zmian społeczno-gospodarczych (Tracz, 2015).

W 2002 r. do polskich szkół ponadgimnazjalnych został wprowadzony przedmiot podstawy przedsiębiorczości. Zgodnie z Rozporzadzeniem Ministra Edukacji Narodowej i Sportu $z$ dnia 26 lutego 2002 r. w sprawie podstawy programowej wychowania przedszkolnego, ksztatcenia ogólnego w poszczególnych typach szkół na lekcjach z tego przedmiotu uczniowie mają uczyć się postaw przedsiębiorczych oraz przygotowywać się do aktywnego udziału w życiu społeczno-gospodarczym. Przedmiot podstawy przedsiębiorczości pomaga zrozumieć młodemu człowiekowi mechanizmy funkcjonowania gospodarki rynkowej, przygotowuje do planowania przyszłej kariery zawodowej, kształtuje kompetencje sprawnego komunikowania się, a także przygotowuje do planowania i realizacji przedsięwzięć w otaczającym go środowisku. Polska jest jedynym krajem w grupie 31 krajów, w tym wszystkich krajów członkowskich UE (Europejska Sieć Informacji o Edukacji, EURYDICE, 2012), gdzie przedsiębiorczość jest realizowana jako obligatoryjny przedmiot nauczania w szkole średniej wyższego poziomu - szkole ponadgimnazjalnej (Tracz, 2015). Cele i treści kształcenia z podstaw przedsiębiorczości od 2002 r. podlegały szerokim dyskusjom i ocenom w odniesieniu do zadań szkoły i oczekiwanych efektów kształcenia (Rachwał, 2009; Rachwał i in., 2008; Wach, 2013). W świetle przyjętej polityki edukacyjnej oraz rozwiązań przedstawionych w dokumentach opracowanych przez MEN należy przyjąć, że przedsiębiorczość to przedmiot przyszłości. Tak też jest on odbierany przez wielu ekonomistów, ekspertów edukacji oraz nauczycieli (Wach, 2013).

Od 2012 r. obowiązkowo wprowadzono przedmiot podstawy przedsiębiorczości w klasach pierwszych szkół ponadgimnazjalnych. Do roku 2012 przedmiot ten realizowany był w klasach trzecich szkół ponadgimnazjalnych. 


\section{Cel i metody badań}

Niniejszy artykuł ma na celu ukazanie poglądów młodzieży uczącej się w Liceum Ogólnokształcącym im. Marii Skłodowskiej-Curie w Andrychowie na temat wybranych zagadnień związanych z realizacją przedmiotu podstawy przedsiębiorczości w szkołach ponadgimnazjalnych.

Badania podjęto, aby dokonać analizy realizacji celów, zadań oraz treści kształcenia przedmiotu podstawy przedsiębiorczości. Głównym celem badań było zapoznanie się z opinią uczniów, które zagadania według nich są najbardziej przydatne w życiu dorosłym oraz które zagadnienia i treści najbardziej ich interesują. Analiza ankiet pokazała zróżnicowane zainteresowania i oczekiwania między ankietowanymi uczniami w roku 2013, jako pierwszoklasistami, a w roku 2015, kiedy byli oni uczniami klasy trzeciej. Badania przeprowadzone w 2013 r., podczas których badani byli uczniowie klas pierwszych oraz trzecich andrychowskiego liceum, pokazały zmienność zainteresowań uczniów przedmiotem podstawy przedsiębiorczości. Uczniowie klas trzecich deklarowali znacznie wyższe zainteresowanie tymi zagadnieniami niż ich koledzy z klas pierwszych. Niewątpliwie wiek, doświadczenie oraz dalsze plany związane z edukacją powodują, że uczniowie klas trzecich znacznie lepiej odbierają ten przedmiot. Natomiast młodzież z klas pierwszych, która rozpoczyna edukację w nowej szkole, bardziej ukierunkowuje swoją uwagę na zajęcia związane z wybieranym profilem kształcenia. Podczas przeprowadzanych badań zarówno w 2013, jak i w 2015 r. uczniowie odpowiadali m.in. na pytania, czy treści przekazywane na lekcjach podstaw przedsiębiorczości pomagają im w przygotowaniu się do dalszego życia społeczno-gospodarczego oraz jakim zagadnieniom na lekcjach poświęcono według uczniów za dużo, a jakim - za mało czasu.

$\mathrm{W}$ artykule zostały przedstawione wyniki badań, które zostały przeprowadzone $\mathrm{w}$ drugim tygodniu kwietnia 2013 r. oraz w maju w 2015 r. na tych samych uczniach andrychowskiego Liceum Ogólnokształcącego im. Marii Skłodowskiej-Curie. Uczniowie ci zostali poddani badaniu powtórnie, po upływie dwóch lat od pierwszego badania. Ankietowani w roku 2013, wówczas jako uczniowie klas pierwszych, zostali poproszeni o wypełnienie kwestionariusza ankietowego, z którego wynikało, że są oni sceptycznie nastawieni do przedmiotu podstawy przedsiębiorczości i uważali, że przedmiot ten powinien być realizowany w klasie trzeciej. Po upływie dwóch lat ci sami uczniowie, już jako trzecioklasiści, zostali poproszeni o powtórne wypełnienie tej samej ankiety. Badanie to miało na celu zweryfikowanie odpowiedzi udzielonych przez nich w 2013 r. oraz sprawdzenie, czy po upływie dwóch lat zmieniły się ich poglądy oraz stosunek do przedmiotu podstawy przedsiębiorczości. Przedmiot ten realizowany jest $\mathrm{w}$ andrychowskim liceum $\mathrm{w}$ systemie jednego roku, przy 2 godzinach lekcyjnych tygodniowo. W sumie w badaniu wzięło udział 392 uczniów (197 uczniów w klasie pierwszej oraz 195 uczniów w klasie trzeciej). W badaniu uczestniczyło 7 oddziałów klas licealnych o następujących profilach: matematyczno-fizycznym, biologiczno-chemicznym, matematyczno-chemicznym, humanistycznym, językowym, przyrodniczym oraz ogólnym. Podczas przeprowadzanego badania w roku 2013 w klasach pierwszych nieobecnych było 21 osób, a w roku 2015 w klasach trzecich - 19 osób. Po analizie ankiet odrzucono $6 \mathrm{z}$ nich z powodu nieczytelności oraz nierzetelności w odpowiedziach (4 ankiety z klas pierwszych w 2013 r. oraz 2 ankiety z klas trzecich w 2015 r.). Ostatecznie uzyskano 386 ankiet, w tym 193 z klas pierwszych i 193 z klas trzecich. Ankieta składała się z 10 pytań (8 pytań ze skalą Likerta).

Podręcznik do przedmiotu podstawy przedsiębiorczości, z którego korzystają andrychowscy uczniowie, to książka autorstwa T. Rachwała oraz Z. Makieły Krok w przedsiębiorczość wydana w Warszawie w 2012 r. w wydawnictwie Nowa Era. 


\section{Wyniki badań}

Pierwsze pytanie dotyczyło tego, czy uczniowie wprowadzenie nowego przedmiotu podstawy przedsiębiorczości do szkół ponadgimnazjalnych i jego funkcjonowanie uważają za słuszny krok w polskiej edukacji. Wyniki przeprowadzonych badań prezentuje ryc. 1.

Prawie 41\% uczniów klas trzecich w roku 2015 uważało, że wprowadzenie przedmiotu podstawy przedsiębiorczości do szkół ponadgimnazjalnych było słuszne, podczas gdy dwa lata wcześniej tylko 16\% z nich odpowiedziało w taki sposób. W 2015 r. 16,6\% uczniów twierdziło, że wprowadzenie przedmiotu podstawy przedsiębiorczości było złym pomysłem, podobna grupa ankietowanych w 2013 r. (uczniowie klas pierwszych) podzielała taką opinię.

Uczniowie klas trzecich andrychowskiego liceum zostali ponownie po upływie dwóch lat od pierwszego badania zapytani o ocenę podręcznika, z którego korzystali w klasie pierwszej. Pytanie dotyczyło tego, czy treści przekazywane w podręczniku są dla nich czytelne i zrozumiałe - 57\% uczniów klas trzecich odpowiedziało, że tak, natomiast w klasie pierwszej takiej odpowiedzi udzieliło 43\% z nich. W 2013 r. 6,3\% ankietowanych uważało, że podręcznik napisany jest niezrozumiałym dla nich językiem, a po upływie dwóch lat tylko 1,4\% spośród nich nie zmieniło zdania i nadal twierdziło, że treści przekazane w podręczniku są nieczytelne i niezrozumiałe (ryc. 2).

Interesujące wydają się wypowiedzi młodzieży dotyczące wykorzystania treści przekazywanych na lekcjach podstaw przedsiębiorczości w dalszym, dorosłym życiu społeczno-gospodarczym. Z przeprowadzonych badań wynika, że uczniowie andrychowskiego liceum zdecydowanie zmienili zdanie w tej kwestii w ciągu dwóch lat, podczas których prowadzone były badania. W roku 2013 uczniowie, będąc pierwszoklasistami, w 36,2\% uważali, że raczej nie wykorzystają w życiu codziennym wiedzy zdobytej na przedmiocie podstawy przedsiębiorczości, podczas gdy dwa lata później, jako trzecioklasiści, udzielili zdecydowanie innej odpowiedzi. Tylko 5,8\% spośród nich podało odpowiedź sugerującą, że nie wykorzystają wiedzy, którą zdobyli w szkole w ramach przedmiotu podstawy przedsiębiorczości. Zaś prawie połowa trzecioklasistów (43\%) jest zdania, że treści przekazywane na lekcjach podstaw przedsiębiorczości pomogły im w przygotowaniu do dalszego życia społeczno-gospodarczego, podczas gdy dwa lata wcześniej tylko 20,7\% z nich udzieliło takiej odpowiedzi (ryc. 3).

Jednym z pytań w kwestionariuszu ankietowym było zagadnienie związane z najbardziej interesującymi i lubianymi treściami kształcenia przez uczniów. Autorka wyodrębniła poszczególne działy tematyczne według kryteriów tematycznych przyjętych z programu nauczania podstaw przedsiębiorczości Z. Makieły i T. Rachwała (2012). Wyniki uzyskane w badaniach ankietowych przeprowadzonych w 2013 i 2015 r. prezentuje ryc. 4.

Najwięcej ankietowanych uczniów z klas trzecich w 2015 r. interesowało się zagadnieniami dotyczącymi problematyki pracy (37\%) i przedsiębiorstwem (33\%). Związane jest to zapewne $\mathrm{z}$ ich wchodzeniem $\mathrm{w}$ dorosłe życie i zainteresowaniami związanymi z podjęciem pracy, która czeka ich w niedalekiej przyszłości. Zainteresowanie klas trzecich tematami związanymi z przedsiębiorstwem wiąże się z chęcią poznania przez nich etapów zakładania przedsiębiorstw i funkcjonowania ich na współczesnym globalnym rynku. Będąc uczniami klas pierwszych, interesowały ich te same tematy co w klasie trzeciej, aczkolwiek w przeciągu dwóch lat spadło ich zainteresowanie zagadnieniami związanymi z pieniądzem i bankowością (z 11,6\% w klasie pierwszej, 1\% w klasie trzeciej) oraz z zagadnieniami związanymi z istotą funkcjonowania gospodarki rynkowej (5,5\% w klasie pierwszej, 0,6\% w klasie trzeciej). Najmniej interesujące treści kształcenia w opinii uczniów zarówno w klasie pierwszej, jak i trzeciej 
Ryc. 1. Opinie uczniów na temat słuszności wprowadzenia przedmiotu podstawy przedsiębiorczości w szkołach ponadgimnazjalnych

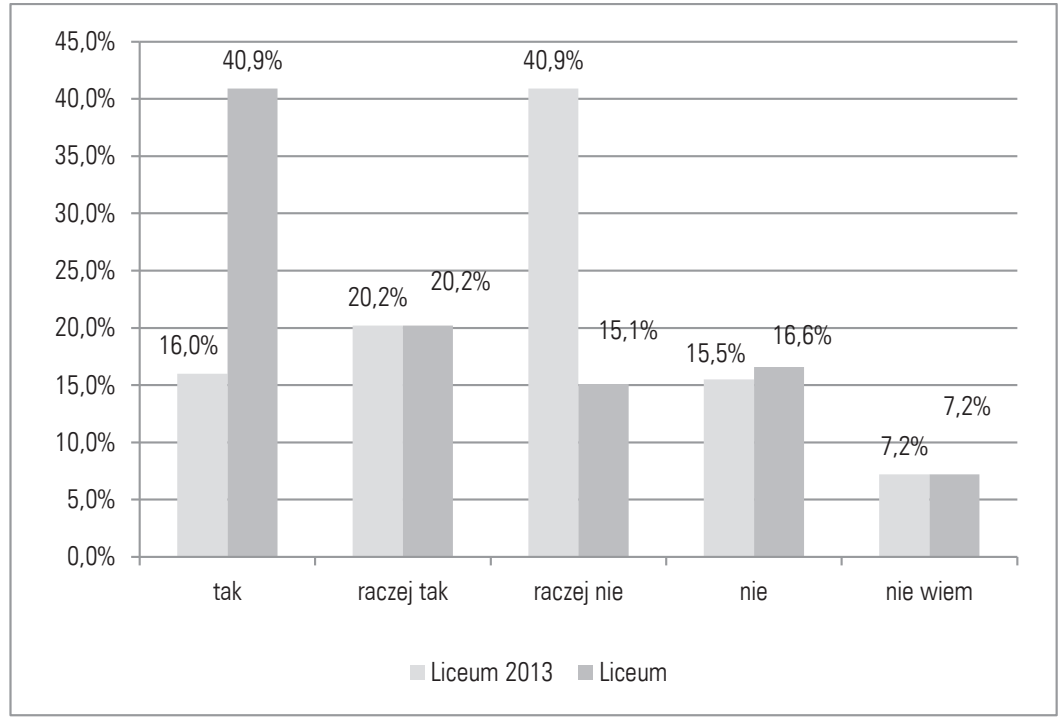

Źródło: opracowanie własne na podstawie badań ankietowych

Ryc. 2. Opinie uczniów na temat tego, czy treści przekazywane w podręczniku są dla nich czytelne i zrozumiałe

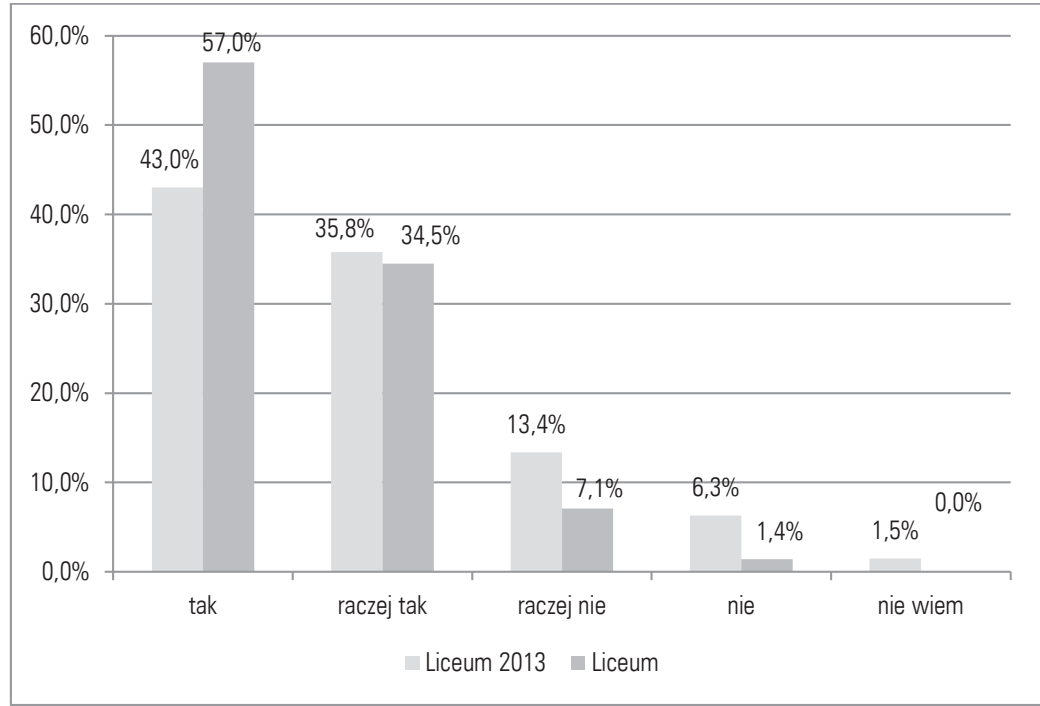

Źródło: opracowanie własne na podstawie badań ankietowych 
Ryc. 3. Opinie uczniów na temat wykorzystania treści przekazywanych na lekcjach podstaw przedsiębiorczości w dalszym, dorosłym życiu społeczno-gospodarczym

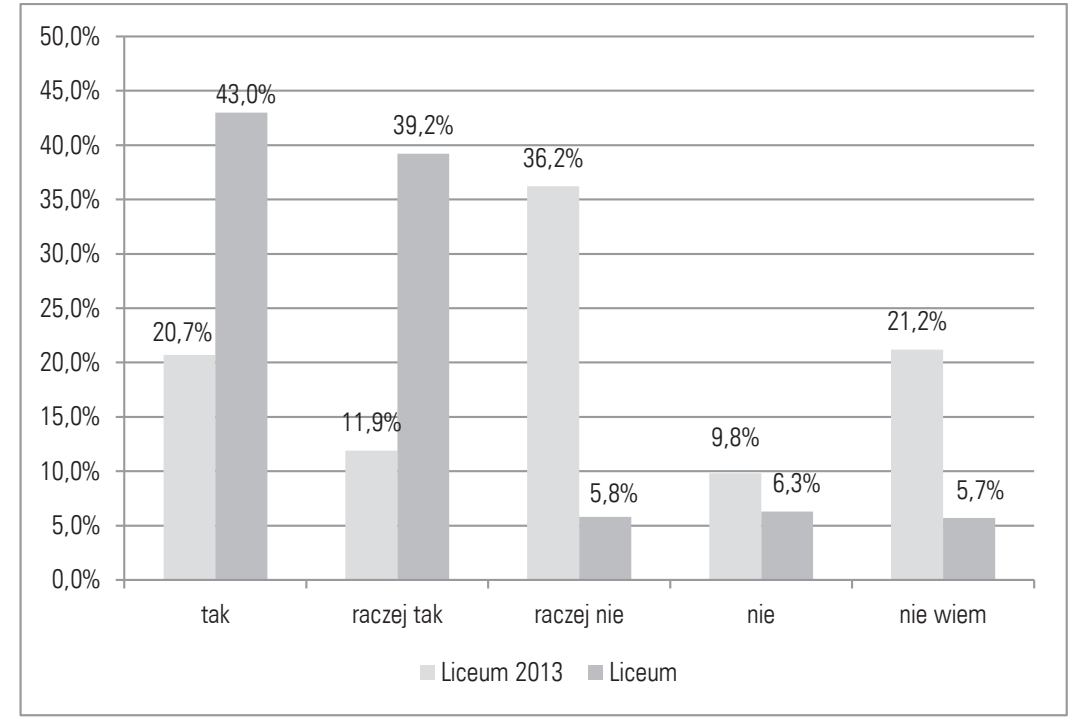

Źródło: opracowanie własne na podstawie badań ankietowych

Ryc. 4. Najbardziej interesujące treści kształcenia w opinii uczniów

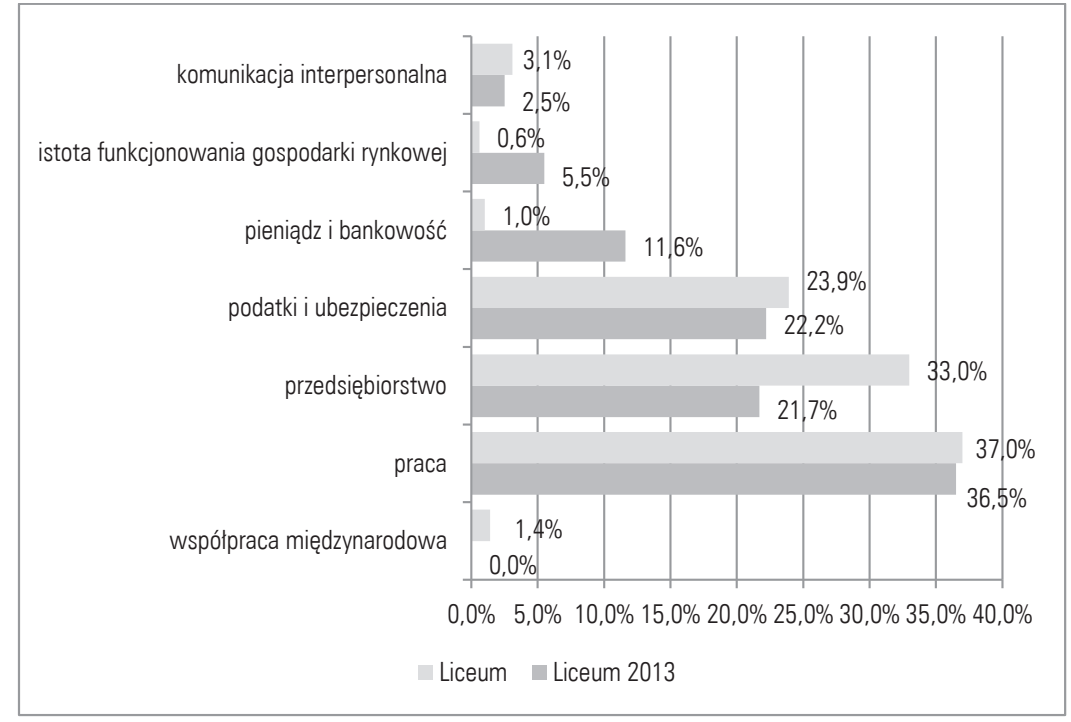

Źródło: opracowanie własne na podstawie badań ankietowych 
to zagadnienia związane ze współpracą międzynarodową oraz z komunikacją interpersonalną. Przedstawiony zestaw tematyki wzbudzającej zainteresowanie badanych uczniów nie odbiega istotnie od wyników uzyskanych przez innych naukowców (E. Osuch, W. Osuch, 2005; Kuklińska, Moranowski, 2009; Osuch, 2012; Ziółkowska-Weiss, 2014). Możemy zatem mówić o akceptacji społecznej uczniów w odniesieniu do podejmowanej tematyki z zakresu przedsiębiorczości w procesie nauczania.

Istotną kwestią w badaniu była chęć poznania opinii uczniów, jakim według nich zagadnieniom na przedmiocie podstawy przedsiębiorczości poświęcono za dużo, a jakim za mało czasu. Odpowiedzi uczniów na to pytanie obrazuje tab. 1.

Tab. 1. Jakim zagadnieniom na przedmiocie podstawy przedsiębiorczości poświęcono według Twojej oceny za dużo, a jakim za mało czasu?

\begin{tabular}{|c|c|c|c|c|c|c|c|c|c|c|}
\hline & \multicolumn{2}{|c|}{$\begin{array}{l}\text { Było tego za } \\
\text { mało (w \%) }\end{array}$} & \multicolumn{2}{|c|}{$\begin{array}{c}\text { Było w sam } \\
\text { raz (w \%) }\end{array}$} & \multicolumn{2}{|c|}{$\begin{array}{l}\text { Było za dużo } \\
\quad \text { (w \%) }\end{array}$} & \multicolumn{2}{|c|}{$\begin{array}{l}\text { Trudno } \\
\text { powiedzieć } \\
(\mathrm{w} \%)\end{array}$} & \multicolumn{2}{|c|}{$\begin{array}{c}\text { Nie było } \\
\text { o tym mowy } \\
\text { na lekcji } \\
(\mathrm{w} \%) \\
\end{array}$} \\
\hline & kl. I & kl. III & kl. I & kl. III & kl. I & kl. III & kl. I & kl. III & kl. I & kl. III \\
\hline $\begin{array}{l}\text { Mocne i słabe cechy } \\
\text { własnej osobowości, } \\
\text { asertywność, umiejętność } \\
\text { podejmowania decyzji } \\
\text { itp. }\end{array}$ & 39,4 & 19,8 & 30,6 & 36,2 & 13,5 & 13,5 & 16,6 & 30,5 & 0,0 & 0,0 \\
\hline $\begin{array}{l}\text { Funkcjonowanie rynku } \\
\text { i gospodarki rynkowej }\end{array}$ & 3,6 & 3,5 & 58,0 & 51,0 & 17,6 & 12,3 & 20,7 & 33,2 & 0,0 & 0,0 \\
\hline $\begin{array}{l}\text { Budżet gospodarstwa } \\
\text { domowego }\end{array}$ & 15,5 & 13,5 & 57,0 & 21,0 & 8,8 & 32,9 & 18,6 & 32,6 & 0,0 & 0,0 \\
\hline $\begin{array}{l}\text { Emerytura } \\
\text { i ubezpieczenia społeczne }\end{array}$ & 6,2 & 51 & 50,2 & 24,8 & 31,6 & 10,1 & 11,9 & 14,2 & 0,0 & 0,0 \\
\hline $\begin{array}{l}\text { Przedsiębiorstwo } \\
\text { w gospodarce. } \\
\text { Funkcjonowanie } \\
\text { przedsiębiorstwa }\end{array}$ & 17,1 & 7,4 & 35,7 & 35,6 & 40,4 & 45,1 & 6,7 & 11,9 & 0,0 & 0,0 \\
\hline $\begin{array}{l}\text { Planowanie podjęcia } \\
\text { działalności gospodarczej }\end{array}$ & 14,5 & 26,5 & 37,8 & 31,5 & 38,3 & 12,3 & 9,3 & 29,7 & 0,0 & 0,0 \\
\hline $\begin{array}{l}\text { Poszukiwanie pracy, } \\
\text { nawiązywanie stosunku } \\
\text { pracy, prawa pracownika }\end{array}$ & 24,8 & 59,2 & 35,2 & 22,3 & 23,8 & 9,2 & 16,1 & 9,3 & 0,0 & 0,0 \\
\hline $\begin{array}{l}\text { Rola państwa } \\
\text { w gospodarce }\end{array}$ & 22,8 & 11,1 & 14,5 & 15,5 & 52,8 & 53,1 & 9,8 & 20,3 & 0,0 & 0,0 \\
\hline Pieniądz i banki & 9,8 & 9,8 & 47,6 & 45,3 & 30,5 & 28,3 & 11,9 & 16,6 & 0,0 & 0,0 \\
\hline Rynek pracy i bezrobocie & 21,2 & 48,6 & 45,0 & 21,0 & 17,6 & 7,9 & 16,1 & 22,5 & 0,0 & 0,0 \\
\hline $\begin{array}{l}\text { Współpraca gospodarcza } \\
\text { Polski z zagranicą }\end{array}$ & 0,0 & 23,6 & 0,0 & 25,6 & 0,0 & 24,3 & 0,0 & 26,5 & 100,0 & 0,0 \\
\hline Etyka biznesu & 0,0 & 9,3 & 0,0 & 46,2 & 0,0 & 20,9 & 0,0 & 20,0 & 100,0 & 3,6 \\
\hline
\end{tabular}

Źródło: opracowanie własne na podstawie badań ankietowych 
Analizując wyniki ankietowe, wyraźnie widać, że uczniowie klas trzecich po upływie dwóch lat od pierwszego badania zmienili zdanie i opinię na temat kwestii związanych z emeryturami i ubezpieczeniami społecznymi oraz związanych z poszukiwaniem pracy. Według uczniów na lekcjach podstaw przedsiębiorczości w klasie pierwszej za mało było kwestii dotyczących emerytur i ubezpieczeń społecznych (6,2\% udzielonych odpowiedzi w klasie pierwszej oraz 51\% udzielonych odpowiedzi w klasie trzeciej). Podobnie przedstawiają się kwestie związane z poszukiwaniem pracy, nawiązywaniem stosunku pracy oraz prawami pracownika $(24,8 \%$ udzielonych odpowiedzi w klasie pierwszej oraz 59,2\% udzielonych odpowiedzi w klasie trzeciej).

Klasy pierwsze, jak pokazały ankiety, nie były w 2013 r. zainteresowane zagadnieniami związanymi z rynkiem pracy i bezrobociem. Tylko 21,2\% uczniów stwierdziło, że zagadnień tych było za mało, podczas gdy dwa lata później takiej odpowiedzi udzieliło dwa razy tyle ankietowanych (48,6\%). Dużą różnicę widać w odpowiedziach związanych z budżetem gospodarstwa domowego. Tylko 8,8\% respondentów (uczniowie pierwszej klasy) odpowiedziało, że było tych zagadnień za dużo, podczas gdy badania przeprowadzone po upływie dwóch lat pokazały, że sądzi tak aż 32,9\% ankietowanych.

Kolejną ważną kwestią w ankiecie było pytanie uczniów o to, w jakim stopniu omawiane treści na lekcji są według nich przydatne w codziennym życiu (tab. 2.).

Tab. 2. W jakim stopniu wymienione niżej kwestie wydają Ci się przydatne w życiu?

\begin{tabular}{|l|c|c|c|c|c|c|c|c|c|c|}
\cline { 2 - 12 } \multicolumn{1}{l|}{} & \multicolumn{2}{|c|}{$\begin{array}{c}\text { W ogóle } \\
\text { nieprzydatne } \\
\text { (w \%) }\end{array}$} & $\begin{array}{c}\text { Raczej } \\
\text { nieprzydatne } \\
\text { (w \%) }\end{array}$ & $\begin{array}{c}\text { Ani } \\
\text { przydatne, } \\
\text { ani } \\
\text { nieprzydatne } \\
\text { (w \%) }\end{array}$ & $\begin{array}{c}\text { Raczej } \\
\text { przydatne } \\
\text { (w \%) }\end{array}$ & \multicolumn{2}{c|}{$\begin{array}{c}\text { Bardzo } \\
\text { przydatne } \\
\text { (w \%) }\end{array}$} \\
\cline { 2 - 13 } & kl. I & kl. III & kl. I & kl. III & kl. I & kl. III & kl. I & kl. III & kl. I & kl. III \\
\hline $\begin{array}{l}\text { Mocne i słabe cechy } \\
\text { własnej osobowości, } \\
\text { asertywność, umiejętność } \\
\text { podejmowania decyzji itp. }\end{array}$ & 0,5 & 0,3 & 5,2 & 5,5 & 18,1 & 28,1 & 40,3 & 31,1 & 35,8 & 18,4 \\
\hline $\begin{array}{l}\text { Funkcjonowanie rynku } \\
\text { i gospodarki rynkowej }\end{array}$ & 19,7 & 11,2 & 7,7 & 7,7 & 46,1 & 32,6 & 6,2 & 23,9 & 20,2 & 24,6 \\
\hline $\begin{array}{l}\text { Budżet gospodarstwa } \\
\text { domowego }\end{array}$ & 6,7 & 9,8 & 14,5 & 13,6 & 26,9 & 26,3 & 17,0 & 30,2 & 34,7 & 21,0 \\
\hline $\begin{array}{l}\text { Emerytura } \\
\text { i ubezpieczenia społeczne }\end{array}$ & 5,7 & 0,0 & 6,7 & 5,4 & 32,6 & 18,6 & 32,6 & 23,9 & 22,3 & 52,1 \\
\hline $\begin{array}{l}\text { Przedsiębiorstwo } \\
\text { w gospodarce. } \\
\text { Funkcjonowanie } \\
\text { przedsiębiorstwa }\end{array}$ & 29,0 & 26,7 & 19,2 & 12,3 & 10,8 & 9,3 & 23,8 & 26,5 & 17,1 & 25,2 \\
\hline $\begin{array}{l}\text { Planowanie podjęcia } \\
\text { działalności gospodarczej }\end{array}$ & 10,4 & 3,2 & 18,6 & 11,6 & 21,2 & 37,3 & 26,4 & 23,6 & 18,1 & 44,3 \\
\hline $\begin{array}{l}\text { Poszukiwanie pracy, } \\
\text { nawiązywanie stosunku } \\
\text { pracy, prawa pracownika }\end{array}$ & 5,2 & 1,1 & 4,1 & 4,1 & 18,1 & 9,1 & 47,1 & 42,1 & 25,4 & 43,6 \\
\hline $\begin{array}{l}\text { Rola państwa } \\
\text { w gospodarce }\end{array}$ & 5,2 & 9,3 & 10,4 & 23,6 & 6,7 & 42,1 & 34,7 & 12,3 & 43,0 & 12,7 \\
\hline
\end{tabular}




\begin{tabular}{|l|r|r|r|r|r|r|r|r|r|r|}
\hline Pieniądz i banki & 10,4 & 10,0 & 20,7 & 21,1 & 46,1 & 46,7 & 5,7 & 5,5 & 11,9 & 11,5 \\
\hline Rynek pracy i bezrobocie & 16,6 & 0,6 & 20,7 & 3,2 & 25,9 & 16,3 & 25,9 & 26,8 & 10,3 & 53,1 \\
\hline $\begin{array}{l}\text { Współpraca gospodarcza } \\
\text { Polski z zagranicą }\end{array}$ & 18,1 & 21,0 & 17,1 & 16,3 & 45,6 & 46,2 & 8,8 & 6,9 & 10,4 & 9,6 \\
\hline Etyka biznesu & 14,5 & 14,5 & 15,5 & 13,6 & 31,1 & 14,6 & 26,9 & 42,3 & 11,9 & 15,0 \\
\hline
\end{tabular}

Źródło: opracowanie własne na podstawie badań ankietowych

Podobnie jak w pytaniu poprzednim uczniowie klas trzecich wskazali większość zagadnień omawianych na lekcjach podstaw przedsiębiorczości jako przydatne z życiu dorosłym. Największe różnice w odpowiedziach w stosunku do klasy pierwszej a trzeciej widoczne są w następujących zagadnieniach: rynek pracy i bezrobocie, poszukiwanie pracy, nawiązywanie stosunku pracy, prawa pracownika, planowanie podjęcia działalności gospodarczej oraz kwestie związane z emeryturami i ubezpieczeniami społecznymi. Badania pokazują, że wszystkie te zagadnienia według klas trzecich były bardzo ważne, podczas gdy ci sami uczniowie, będąc $\mathrm{w}$ klasie pierwszej, mieli inne zdanie. Widoczna różnica jest także w kwestii związanej z rolą państwa w gospodarce. Większa liczba trzecioklasistów w stosunku do pierwszej klasy uważa, że jest to zagadnienie w ogóle niepotrzebne w życiu (9,3\% w 2015 r.).

Dużą rolę w procesie dydaktycznym musi odgrywać praktyka i umiejętność posługiwania się dokumentami potrzebnymi w życiu społeczno-gospodarczym. Dlatego uzasadnione jest pytanie do uczniów dotyczące tego, jakie praktyczne umiejętności opanowali na lekcjach podstaw przedsiębiorczości. Szczegółowe dane przedstawia tabela 3.

Tab. 3. Czy wymienionych poniżej umiejętności nauczyłeś(aś) się na przedmiocie podstawy przedsiębiorczości?

\begin{tabular}{|l|c|c|c|c|c|c|}
\cline { 2 - 8 } \multicolumn{1}{c|}{} & \multicolumn{2}{|c|}{ Tak (w \%) } & \multicolumn{2}{c|}{ Nie (w \%) } & \multicolumn{2}{c|}{$\begin{array}{c}\text { Trudno } \\
\text { powiedzieć (w \%) }\end{array}$} \\
\cline { 2 - 8 } \multicolumn{1}{c|}{} & kl. I & kl. III & kl. I & kl. III & kl. I & kl. III \\
\hline Jak obliczyć odsetki od lokaty? & 21,7 & 25,9 & 48,1 & 41,6 & 30,1 & 32,5 \\
\hline Jak założyć firmę? & 46,1 & 62,1 & 23,3 & 29,3 & 30,6 & 8,4 \\
\hline Jak napisać dobre CV? & 62,2 & 82,3 & 17,1 & 5,4 & 15,5 & 11,3 \\
\hline Jak wypełnić formularz PIT? & 52,3 & 52,3 & 21,8 & 31,2 & 25,9 & 16,5 \\
\hline Jak negocjować? & 31,0 & 31,0 & 23,8 & 23,0 & 45,0 & 45,8 \\
\hline $\begin{array}{l}\text { Jak planować budżet gospodarstwa } \\
\text { domowego? }\end{array}$ & 45,6 & 32,6 & 19,2 & 31,2 & 35,2 & 36,2 \\
\hline Jak dokonać autoprezentacji? & 14,5 & 12,6 & 65,7 & 69,3 & 21,8 & 18,1 \\
\hline Jak zaplanować swój rozwój zawodowy? & 20,7 & 56,3 & 48,1 & 23,6 & 31 & 20,1 \\
\hline $\begin{array}{l}\text { Jak przewidzieć opłacalność jakiegoś } \\
\text { przedsięwzięcia gospodarczego? }\end{array}$ & 16,0 & 6,3 & 74,0 & 85,8 & 9,8 & 7,9 \\
\hline Jak wykonać biznesplan? & 68,4 & 74,6 & 11,3 & 4,5 & 20,2 & 20,9 \\
\hline
\end{tabular}

Źródło: opracowanie własne na podstawie badań ankietowych 
Odpowiedzi na to pytanie pokazały, że uczniowie i w pierwszej, i trzeciej klasie odpowiadali bardzo podobnie. Uznali oni, zarówno w klasie pierwszej, jak i trzeciej, że na lekcjach z zakresu podstaw przedsiębiorczości nauczyli się takich rzeczy, jak: wykonywanie biznesplanu, planowanie budżetu gospodarstwa domowego, wypełnianie formularza PIT, pisanie CV oraz dowiedzieli się, jak założyć firmę. Nie opanowali natomiast kwestii związanych z przewidywaniem opłacalności przedsięwzięcia gospodarczego, obliczaniem odsetek od lokaty oraz z prawidłową sztuką autoprezentacji. Różnica w odpowiedziach w przeciągu dwóch lat widoczna jest w odpowiedzi dotyczącej planowania rozwoju zawodowego. Ponad połowa uczniów klas trzecich w 2015 r. zadeklarowała, że to potrafi, podczas gdy w klasie pierwszej w 2013 r. tylko $20,7 \%$ z nich udzieliło takiej odpowiedzi.

Ostatnie pytanie miało na celu poznanie opinii uczniów na temat przeprowadzonej reformy oraz czy przedmiot podstawy przedsiębiorczości według nich jest przedmiotem ważnym i należy go nauczać we wszystkich typach szkół ponadgimnazjalnych. Odpowiedzi na poszczególne pytanie pokazuje tab. 4 .

Tab. 4. W jakim stopniu zgadzasz się z każdym z niżej przedstawionych twierdzeń?

\begin{tabular}{|c|c|c|c|c|c|c|c|c|c|c|}
\hline & \multicolumn{2}{|c|}{$\begin{array}{c}\text { Zdecydowanie } \\
\text { się nie } \\
\text { zgadzam } \\
\text { (w \%) }\end{array}$} & \multicolumn{2}{|c|}{$\begin{array}{l}\text { Raczej się } \\
\text { nie zgadzam } \\
\quad(w \%)\end{array}$} & \multicolumn{2}{|c|}{$\begin{array}{l}\text { Trudno } \\
\text { powiedzieć } \\
(w \%)\end{array}$} & \multicolumn{2}{|c|}{$\begin{array}{l}\text { Raczej się } \\
\text { zgadzam } \\
(\mathrm{w} \%)\end{array}$} & \multicolumn{2}{|c|}{$\begin{array}{l}\text { Zdecydowani } \\
\text { się zgadzam } \\
(\mathbf{w} \%)\end{array}$} \\
\hline & kl. I & kl. III & kl. I & kl. III & kl. I & kl. III & kl. I & kl. III & kl. I & kl. III \\
\hline $\begin{array}{l}\text { Podstawy } \\
\text { przedsiębiorczości to } \\
\text { przedmiot mało ważny } \\
\text { w szkole }\end{array}$ & 3,1 & 25,6 & 3,1 & 26,9 & 20,7 & 35,6 & 45,0 & 9,6 & 27,9 & 2,3 \\
\hline $\begin{array}{l}\text { Włożyłem(am) } \\
\text { dużo pracy } \\
\text { w opanowanie treści } \\
\text { przedmiotu podstawy } \\
\text { przedsiębiorczości }\end{array}$ & 10,3 & 12,6 & 24,8 & 31,2 & 38,8 & 36,6 & 5,2 & 9,6 & 20,7 & 2,3 \\
\hline $\begin{array}{l}\text { Podstawy } \\
\text { przedsiębiorczości } \\
\text { powinny zniknąć } \\
\text { z programu szkolnego }\end{array}$ & 6,2 & 9,3 & 4,1 & 12,3 & 46,1 & 49,8 & 23,8 & 16,3 & 19,6 & 3,9 \\
\hline $\begin{array}{l}\text { Przedmiot podstawy } \\
\text { przedsiębiorczości } \\
\text { powinien być nauczany } \\
\text { tylko w szkołach } \\
\text { ekonomicznych } \\
\end{array}$ & 5,2 & 35,6 & 6,2 & 5,2 & 22,2 & 32,6 & 33,6 & 21,5 & 32,6 & 5,1 \\
\hline \begin{tabular}{|l|} 
Przedmiot podstawy \\
przedsiębiorczości \\
powinien być nauczany \\
w III klasie liceum \\
\end{tabular} & 24,8 & 10,1 & 16,6 & 6,5 & 49,2 & 46,7 & 6,2 & 21,7 & 3,1 & 14,8 \\
\hline $\begin{array}{l}\text { Przedmiot podstawy } \\
\text { przedsiębiorczości } \\
\text { powinien być nauczany } \\
\text { w I klasie liceum }\end{array}$ & 10,3 & 21,5 & 0,5 & 26,2 & 42,4 & 19,6 & 39,3 & 19,6 & 29,0 & 13,0 \\
\hline
\end{tabular}

Źródło: opracowanie własne na podstawie badań ankietowych 
Jak pokazują wyniki badań, stosunek uczniów do przedmiotu podstawy przedsiębiorczości w klasie pierwszej zdecydowanie różni się od ich opinii na ten temat jako uczniów klas trzecich. Aż 25,6\% uczniów w klasie trzeciej stwierdziło, że przedmiot podstawy przedsiębiorczości zdecydowanie jest przedmiotem ważnym w szkole ponadgimnazjalnej. Taką opinię podzielało jedynie 3,1\% spośród nich w klasie pierwszej. Podobnie wyglądają odpowiedzi udzielane na pytanie dotyczące tego, czy przedmiot podstawy przedsiębiorczości powinien być nauczany tylko w szkołach ekonomicznych. Ze stwierdzeniem tym zdecydowanie nie zgadzało się jedynie 5,2\% pierwszoklasistów, podczas gdy w klasie trzeciej uczniów takich było aż 35,6\%. Zadziwiające są wyniki prezentujące opinię uczniów dotyczące tego, w której klasie szkoły ponadgimnazjalnej przedmiot ten powinien być realizowany. W 2013 r. pierwszoklasiści odpowiedzieli, że przedmiot powinien być nauczany w klasie trzeciej $(24,8 \%)$, a dwa lata później, jako uczniowie klasy trzeciej, udzielili odpowiedzi, że przedmiot ten powinien być nauczany w klasie pierwszej (21,5\%).

\section{Zakończenie}

Z przeprowadzonych badań wynika, że przedmiot podstawy przedsiębiorczości spełnia oczekiwania większości ankietowanych uczniów. Wydaje się także, iż wśród uczniów andrychowskiego liceum podstawy przedsiębiorczości w obecnej formie są przedmiotem praktycznym, ale mało konkretnym, bez solidnej podbudowy teoretycznej. Młodzi ludzie mają wyraźnie sprecyzowaną ścieżkę swojej kariery zawodowej i na tym etapie nie oczekują innych propozycji czy zmian. Pochłonięci pasją nauki w swoich specjalnościach i profilach nie interesują się praktycznymi rozwiązaniami, na które być może przyjdzie czas w późniejszych latach.

Na podstawie przeprowadzonych ankiet można wyciągnąć następujące wnioski:

- uczniowie andrychowskiego liceum po dwóch latach od przeprowadzenia pierwszego badania udzielili innych odpowiedzi na postawione im te same pytania. Różnice w odpowiedziach widoczne są m.in. w kwestiach dotyczących emerytur i ubezpieczeń społecznych oraz w kwestiach związanych z poszukiwaniem pracy;

- 41\% uczniów klas trzecich w 2015 r. uważało, że wprowadzenie przedmiotu podstawy przedsiębiorczości do szkół ponadgimnazjalnych było słuszne, podczas gdy dwa lata wcześniej tylko $16 \%$ z nich odpowiedziało w taki sposób;

- w 2013 r. 36,2\% uczniów będących pierwszoklasistami uważało, że raczej nie wykorzystają w życiu codziennym wiedzy zdobytej na przedmiocie podstawy przedsiębiorczości, podczas gdy dwa lata później, jako trzecioklasiści, udzielili zdecydowanie innej odpowiedzi $(5,8 \%)$;

- $43 \%$ trzecioklasistów była zdania, że treści przekazywane na lekcjach podstaw przedsiębiorczości pomogły im w przygotowaniu się do dalszego życia społeczno-gospodarczego, podczas gdy dwa lata wcześniej w roku 2013 tylko 20,7\% z nich udzieliło takiej odpowiedzi;

- w przeciągu dwóch lat prowadzenia badań spadło zainteresowanie uczniów zagadnieniami związanymi z pieniądzem i bankowością (z 11,6\% w klasie pierwszej do $1 \% \mathrm{w}$ klasie trzeciej) oraz z zagadnieniami związanymi z istotą funkcjonowania gospodarki rynkowej (5,5\% w klasie pierwszej, 0,6\% w klasie trzeciej);

- najmniej interesujące treści kształcenia w opinii uczniów, zarówno w klasie pierwszej, jak i w trzeciej, to zagadnienia związane ze współpracą międzynarodową oraz komunikacją interpersonalną; 
- uczniowie, zarówno w klasie pierwszej, jak i trzeciej, stwierdzili, że na lekcjach podstaw przedsiębiorczości nauczyli się takich rzeczy, jak: wykonywanie biznesplanu, planowanie budżetu gospodarstwa domowego, wypełnianie formularza PIT, pisanie CV, oraz dowiedzieli się, jak założyć firmę;

- stosunek uczniów do przedmiotu podstawy przedsiębiorczości w klasie pierwszej zdecydowanie różni się od ich opinii na ten temat jako uczniów klas trzecich;

- 25,6\% uczniów w klasie trzeciej stwierdziło, że zdecydowanie przedmiot podstawy przedsiębiorczości jest przedmiotem ważnym w szkole ponadgimnazjalnej; taką opinię podzielało jedynie 3,1\% spośród nich w klasie pierwszej;

- w 2013 r. pierwszoklasiści odpowiedzieli, że przedmiot ten powinien być nauczany w klasie trzeciej (24,8\%), a dwa lata później, jako uczniowie klasy trzeciej, udzielili odpowiedzi, że przedmiot ten powinien być nauczany w klasie pierwszej $(21,5 \%)$.

Bardzo ważną rolę w procesie dydaktycznym musi odgrywać nauczyciel. To on powinien pobudzać swoich uczniów do twórczego zachowania oraz inspirować ich do działań. W andrychowskim liceum ogólnokształcącym w roku szkolnym 2012/2013, kiedy badania dotyczące przedmiotu podstawy przedsiębiorczości przeprowadzane były po raz pierwszy, w 15 oddziałach uczyło w sumie 3 nauczycieli tego przedmiotu. W roku szkolnym 2014/2015, kiedy badania prowadzone były ponownie, a przedmiot ten nauczany był jedynie w 6 pierwszych oddziałach klasowych, nauczycieli uczących tego przedmiotu było tylko 2. Ważne jest, aby nauczyciel przedsiębiorczości posiadał autorytet wśród swoich uczniów i ich aktywizował. Na pewno wysoko ceniony jest nauczyciel kreatywny i posiadający wiedzę merytoryczną z przedmiotu. To w dużej mierze od nauczyciela zależy, czy uczniowie polubią dany przedmiot i czy wiedza zdobyta na nim będzie wykorzystywana przez młodych ludzi w późniejszym, dorosłym życiu. Nauczyciele andrychowskiego liceum angażują uczniów w dodatkowe, pozalekcyjne projekty związane z przedsiębiorczością. Uczniowie co roku biorą udział w licznych przedsięwzięciach, takich jak np.: SIGG (Szkolna Internetowa Gra Giełdowa), e-learning organizowany przez Giełdę Papierów Wartościowych, lekcja z ZUS-em, Chłopska Szkoła Biznesu, uczestniczą również w różnych przedsięwzięciach organizowanych w połowie listopada w ramach tzw. tygodnia przedsiębiorczości. Nauczyciele przedsiębiorczości $\mathrm{w}$ andrychowskim liceum zapraszają na lekcję bezrobotnych, osoby z inkubatorów przedsiębiorczości czy samorządowców andrychowskiej gminy. O kompetencjach przedmiotowych i dydaktycznych nauczycieli geografii, w tym także uczących podstaw przedsiębiorczości, pisał w obszernej monografii W. Osuch (2010), wskazując przykłady kształtowania wybranych kompetencji w toku studiów i pracy zawodowej nauczycieli. Ważnymi kompetencjami, nie tylko u nauczycieli przedsiębiorczości, są kompetencje komunikacyjne, co było przedmiotem rozważań W. Osucha (2011), oraz ocena tych kompetencji, co zostało również potwierdzone w wynikach badań ankietowych, zwłaszcza wśród rodziców uczniów z liceów krakowskich. O kompetencjach odnoszących się bezpośrednio do przedsiębiorczości i postaw przedsiębiorczych pisali: S. Dorocki, W. Kilar i T. Rachwał (2011), podkreślając też kreatywność, innowacyjność, podejmowanie ryzyka oraz planowanie przedsięwzięć jako cechy istotne osiągania zamierzonych celów. Ponadto autorzy ci przypomnieli kompetencje kluczowe stosowane w europejskim obszarze edukacyjnym.

W świetle zmian programowych wdrożonych w 2009 r. w polskim systemie oświaty rodzi się pytanie, na ile przyjęte rozwiązania kształcenia w zakresie przedsiębiorczości w szkole ogólnokształcącej spełniają swoją funkcję. Nie jest to przedmiot maturalny, nie są nim także zainteresowane uczelnie ekonomiczne przy rekrutacji studentów. Nauczanie 
tego przedmiotu ukierunkowane jest raczej na rozumienie elementarnych procesów ekonomicznych i gospodarczych oraz opanowanie podstawowych umiejętności. Powoduje to, że przedmiot traktowany jest przez wielu uczniów i nauczycieli jako przedmiot praktyczny. Fakty te nie pozostają bez wpływu na opinie uczniów i rodziców o przedmiocie i jego realnej randze w procesie kształcenia, co potwierdziły badania nad zainteresowaniem uczniów tym przedmiotem (Tracz, 2006). Czas pokaże, czy zainteresowanie tym przedmiotem oraz wykorzystanie treści kształcenia przedsiębiorczości w karierze zawodowej i życiu społeczno-gospodarczym będzie większe.

Literatura

References

Dorocki, S., Kilar, W., Rachwał, T. (2011). Założenia i cele Projektu „Krok w przedsiębiorczość” dla nauczycieli szkół ponadgimnazjalnych. Przedsiębiorczość - Edukacja, 7, 308-320.

Kuklińska, K., Moranowski, P. (2009; 2015, 10 września). Przedmiot podstawy przedsiębiorczości oczami nauczycieli i uczniów szkót ponadgimnazjalnych. Raport z badań. Pozyskane z: www. file/C:Users/nicon/Dowlands/Raport\%20badan.pdf

Makieła, Z., Rachwał, T. (2012). Krok w przedsiębiorczość. Podręcznik do podstaw przedsiębiorczości dla szkót ponadgimnazjalnych. Warszawa: wydawnictwo Nowa Era.

Osuch, E., Osuch, W. (2005). Przedmiot podstawy przedsiębiorczości w opinii uczniów i rodziców na przykładzie wybranych krakowskich szkół. Przedsiębiorczość - Edukacja, 1, 195-202.

Osuch, W. (2010). Kompetencje przedmiotowe i dydaktyczne nauczycieli geografii oraz studentów geografii - kandydatów na nauczycieli. Prace Monograficzne, 570. Kraków: Wydawnictwo Naukowe Uniwersytetu Pedagogicznego.

Osuch, W. (2011). Kompetencje w zakresie komunikacji interpersonalnej w dobie postępujących procesów globalizacji. Przedsiębiorczość - Edukacja, 7, 333-346.

Osuch, W. (2012). Podstawy przedsiębiorczości w opinii uczniów krakowskich liceów - szanse i oczekiwania. Przedsiębiorczość - Edukacja, 8, 37-47.

Rachwał, T. (2009). Ocena projektu zmian podstawy programowej podstaw przedsiębiorczości. Przedsiębiorczość - Edukacja, 5, 349-372.

Rachwał, T., Kilar, W., Kudełko, J., Tracz, M., Wach, K. (2008). Projekt podstawy programowej podstaw przedsiębiorczości w zakresie rozszerzonym dla liceum ogólnokształcącego, liceum profilowanego i technikum. Przedsiębiorczość - Edukacja, 4, 312-324.

Rozporzadzenie Ministra Edukacji Narodowej i Sportu z dnia 26 lutego 2002 r. w sprawie podstawy programowej wychowania przedszkolnego, kształcenia ogólnego w poszczególnych typach szkół (Dz.U. z 2002 r. Nr 51, poz. 458).

Tracz, M. (2005). O niektórych kryteriach doboru treści nauczania do podstawy programowej i programu nauczania z podstaw przedsiębiorczości. Przedsiębiorczość - Edukacja, 1, 207-211.

Tracz, M. (2006). Rola i znaczenie podstaw przedsiębiorczości w kształceniu ogólnym. Przedsiębiorczość Edukacja, 2, 222-225.

Tracz, M. (2015). Przedmiot podstawy przedsiębiorczości w opinii uczniów i nauczycieli - studium porównawcze. Przedsiębiorczość - Edukacja, 11, 391-400.

Tracz, M., Rachwał, T. (2007). Przedmiot podstawy przedsiębiorczości - założenia realizacji a przygotowanie nauczycieli. Przedsiębiorczość - Edukacja, 3, 286-296.

Wach, K. (2013). Edukacja na rzecz przedsiębiorczości wobec współczesnych wyzwań cywilizacyjno-gospodarczych. Przedsiębiorczość - Edukacja, 9, 246-256.

Ziółkowska-Weiss, K. (2014). Problematyka podstaw przedsiębiorczości w opinii uczniów szkoły ponadgimnazjalnej. Przydatność w życiu czy konieczność nauki? Przedsiębiorczość - Edukacja, 10, 366-376. 
Kamila Ziółkowska-Weiss, dr, absolwentka kulturoznawstwa na Uniwersytecie Jagiellońskim oraz geografii na Uniwersytecie Pedagogicznym w Krakowie. Ukończyła podyplomowe studia na Uniwersytecie Ekonomicznym w Krakowie na kierunku zarządzanie turystyką międzynarodową. Od 2012 r. pracownik naukowy na stanowisku asystent w Zakładzie Turystyki i Badań Regionalnych Uniwersytetu Pedagogicznego w Krakowie. Czynny pilot wycieczek. Autorka kilku publikacji naukowych. Główne zainteresowania naukowe to turystyka kulturowa, mniejszości narodowe i grupy etniczne w Małopolsce oraz Polonia w USA.

Kamila Ziółkowska-Weiss, PhD, graduate of Culture Studies at the Jagiellonian University and of Geography on the Pedagogical University in Cracow. She has graduated from postgraduate studies in international tourism management at the Cracow University of Economics. Since 2012 she has been a research worker, acting as an assistant in the department of Tourism and Regional Studies on the Pedagogical University in Cracow. An active tourist guide. The author of several academic publications. Her main academic interests are in cultural tourism, ethnic groups in Małopolska and Polish minority in USA.

\section{Adres/Address:}

Uniwersytet Pedagogiczny im. Komisji Edukacji Narodowejw Krakowie Instytut Geografii

Zakład Turystyki i Badań Regionalnych

ul. Podchorążych 2

30-084 Kraków, Polska

e-mail: kamilacamela@wp.pl 